\title{
PHYTOCHEMICAL AND PHARMACOLOGICAL STUDY OF POLYSACCHARIDE COMPLEXES OF PRUNUS DOMESTICA FRUIT
}

\author{
(c) T. Upyr, Shahm Basim Mohammed, Bashar Al-Jabbar Ali Sahlani, L. Lenchyk, I. Senyuk, \\ V. Kyslychenko
}

\begin{abstract}
Мета. Метою нашої роботи було провести фракціонування полісахаридних комплексів з свіжих плодів сливи, дослідити елементний склад свіжих плодів сливи, провести порівняльне дослідження вмісту нейтральних моноцукрів у одержаних комплексах, та дослідити їх вплив на гістоструктуру печінки щурів в умовах етанольної інтоксикачії
\end{abstract}

Методи. Аналіз макро- та мікроелементів проводили на атомно-емісійному спектрофотометрі ISE 3500 (Thermo Scientific, CША). Вміст полісахаридних фракиій, таких як: волокна, водорозчинний полісахаридний комплекс (ВПК) та пектин, проводили гравіметричним методом. Порівняльне вивчення вмісту моносахаридів у отриманих фракціях проводили з додаванням пікринової кислоти на спектрофотометрі Hewlett Packerd 8453 при довжині хвилі 463 нм у кюветі з товщчиною шару 10 мм.

Досліджено вплив волокон та ВПК плодів сливи на гістоструктуру печінки щурів на моделі інтоксикаціі етанолом.

Результати. У результаті досліджень визначено елементний склад плодів сливи з найбільшим вмістом калію - 2000 мкг/100г. Вміст важких металів у плодах сливи не перевищував норм, встановлених Державною фармакопеєю України. Зі свіжих плодів сливи були отримані три фракиї полісахаридів: волок-

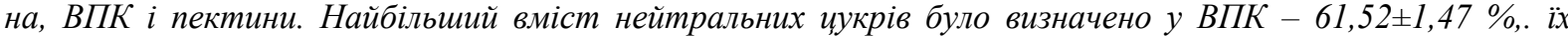

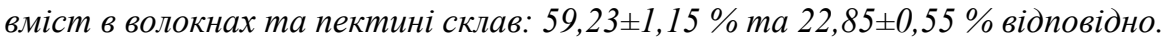

Було підтверджено, щзо одночасне вживання етанолу з волокнами плодів сливи в дозі 200 мг/кг запобігає розвитку жирової дистрофії паренхіми печінки, на відміну від аналогічної схеми введення ВПК плодів сливи у тій самій дозі та препарату порівняння силібор в дозі 30 мг/кг.

Висновки. Враховуючи результати фітохімічних та фармакологічних досліджень, можна зробити висновок, щуо волокна плодів сливи є перспективними для подальшого дослідження з метою створення нових ефективних $і$ безпечних лікарських засобів з метою їх використання в медичній практиці

Ключові слова: слива, екстракт, полісахариди, елементи, гістоструктура, печінка щурів, інтоксикація етанолом

\section{Introduction}

Nowadays, agricultural crops became the main focus of researchers due to fact they are a good sources of biologically active substances, yielding a sufficient raw material base. Most of them have been used in traditional medicinal practice since the prehistoric times. Phytochemical study of plants is used to find potentially promising plants for the development of new drugs. Plum (Prunus domestica, family Rosaceae) is widely cultivated in Ukraine as horticultural crops. Plum has long been used in traditional medicine and its usage is still actual [1].

2. Formulation of the problem in a general way, the relevance of the theme and its connection with important scientific and practical issues

During our preliminary study from dried plum fruits, polysaccharide complexes, water and alcohol extracts were obtained. Laxative activity of all obtained substances was studied by the Sticknay J. S. method [2]. Further investigation of polysaccharides complexes isolated from fresh plum fruits will help expand the raw material base and are necessary to determine constituents, safety and efficacy of the most effective extracts.
3. Analysis of recent studies and publications in which a solution of the problem and which draws on the author

The important role of fruits in human health and nutrition has been better understood with the recent studies on biochemical contents of fruits having antioxidant properties. In recent studies and publications total antioxidant capacity, phenolic compound, organic acid, and vitamin $\mathrm{C}$ contents of different plum species were determined and the correlation between the measured values was investigated [3, 4]. Analysis of phenolic compound indicated that chlorogenic acid was the predominant phenolic compound [3]. Laxative effect of different extracts from dried plum was confirmed [4]. For the standardization of plum fruits as herbal raw material, according to the methods of the State Pharmacopoeia of Ukraine the indexes of fresh plum were determined $[5,6]$.

Therefore, further study of influence of fibers and WSPC on histostructure of liver of rats in conditions of ethanol intoxication was actually, interesting and expedient. 
4. Allocation of unsolved parts of the general problem, which is dedicated to the article

Plum is good sources of biologically active substances. At the base of review of modern research and our preliminary study it was confirmed, that plum - is rich on hydroxycinnamic acids, organic acids and polysaccharides. Moreover cathartic effect for row of isolated complexes were determined. Therefore, study of polysaccharide complexes in detail is prospective in development of new active pharmaceutical ingredients and creation of methods of quality control.

\section{Formulation of goals (tasks) of article}

The aim of our research was fractionation of polysaccharide complexes from fresh plum fruits, comparative study content of neutral sugars in it, element composition of plum fruit and investigation of influence of fibers and water soluble polysaccharide complex (WSPC) on histostructure of rats liver in conditions of ethanol intoxication.

\section{Statement of the basic material of the study (methods and objects) with the justification of the results}

In August 2017 the plant material (fresh plum fruits of varieties "Ugorka") were purchased on the market in Kharkiv, Ukraine. Plant raw material was pitted and grinded to the puree. Determination of the loss of drying of plum fruits were carried out according to the SPU requirement [6]

Three polysaccharide substances as fibers, WSPC and pectin were isolated from plum raw material sequentially.

For the isolation of fibers, hot water was added to the $100 \mathrm{~g}$ of pitted crushed plum fruit in the ratio 1:5, stirred for 1 hour at room temperature. Fibers were centrifuged (speed of rotation of $5000 \mathrm{rpm}$ ) during 10 minutes. Obtained fibers were dried in an oven to constant weight at the temperature $100-105^{\circ} \mathrm{C}$ and yield was determined.

Water extract were decanted in a flask, evaporated to $50 \mathrm{ml}$ and placed in a flask with capacity of $500 \mathrm{ml}$, after that $150 \mathrm{ml}$ of $96 \%$ alcohol was added and mixed. Precipitate (WSPC) was filtered through a paper filter. The filter with the WSPC was dried firstly in air and then to constant weight at the temperature $100-105{ }^{\circ} \mathrm{C}$ and yield was calculated.

The water extract remaining after receiving WSPC was evaporated to $50 \mathrm{ml}$ and used to obtain the pectin faction. Pectin was extracted with a mixture of $0.5 \%$ solution of ammonium oxalate and $0.5 \%$ solution of acid oxalate (1:1) at a ratio of 1:20. Extraction was performed twice at a temperature of $80-85^{\circ} \mathrm{C}$ during 2 hours. The resulting extract was filtered, pooled and evaporated to $1 / 5$ of the original volume. Pectin was precipitated by three volumes of $95 \%$ ethanol, and settling for 12 hours in a cool place. The precipitate was filtered, washed with $95 \%$ ethanol and dried in a drying oven to constant weight. Yield of pectin was determined.

For comparative study of obtained polysaccharide complexes $0.5 \mathrm{~g}$ of each obtained fractions were hydrolysed with a hydrochloric acid concentrated for 2.5 hours. The solutions were cooled and quantitatively transferred with water to volumetric flasks with a capacity of $25.0 \mathrm{ml}$, adjusted to the mark with the same solvent and mixed. Then were taken $5 \mathrm{ml}$ from each obtained solution and neutralized by the solution of $30 \%$ sodium hydroxide with universal indicator paper. The neutralized solution was filtered through a paper filter, transferred quantitatively to a $25.0 \mathrm{ml}$ volumetric flask, diluted to volume with water, and stirred.

Then $2-5 \mathrm{ml}$ of the solution were taken from the each volumetric flask into other $25.0 \mathrm{ml}$ capacity volumetric flasks, $1.0 \mathrm{ml}$ of $1 \%$ picric acid, $3.0 \mathrm{ml}$ of $20 \%$ sodium carbonate were added in each flasks and heated at $100{ }^{\circ} \mathrm{C}$ for 20 minutes. After cooling, the volume was adjusted with water and stirred. In parallel, under the same conditions, $2.0 \mathrm{ml}$ of a standard sample (SS) of glucose was prepared. The optical density of the test and glucose SS solutions were measured on a Hewlett Packard 8453 spectrophotometer at a wavelength of $463 \mathrm{~nm}$ in a cuvette with a layer thickness of 10 $\mathrm{mm}$. A mixture consisting of $1.0 \mathrm{ml}$ of $1 \%$ picric acid, 3 $\mathrm{ml}$ of $20 \%$ sodium carbonate and $1.0 \mathrm{ml}$ of water was used as the reference solution [7].

The study of the content of macro- and microelements is important for further standardization and the development of quality control procedures. The elemental composition was determined with atomic emission spectrophotometer at State Scientific Institution "Institute for Single Crystals" of NAS of Ukraine. To obtain spectra and their registration plate spectrograph DFS-8 ISE 3500 (Thermo Scientific, USA) with a diffraction grating 600 line/mm and Trilinz Slot Lighting was used. The sample was evaporated from the craters of graphite electrodes in the discharge arc of an alternating current of $16 \mathrm{~A}$ with an exposure of 60 seconds. As an excitation source of spectra, IWS-28 was used. Measuring intensities of lines in the spectra of analyzed samples and calibration samples was carried out with micro photometer MF-1 $[8,9]$.

The material for histological examination was the liver of rats after 7-10 days of intraperitoneal injection of $40 \mathrm{~g}$ of ethyl alcohol in a dose of $7 \mathrm{ml} / \mathrm{kg}$ - control pathology; liver of rats, which daily 1 hour after the introduction of ethyl alcohol for 7-10 days, received plum fibers or plum WSPC in a dose of $200 \mathrm{mg} / \mathrm{kg}$, or Silibor (preparation of comparison) in a dose of $30 \mathrm{mg} / \mathrm{kg}$; liver of intact rats - intact control. The withdrawal from the experiment of rats of all groups was carried out on the second day after the completion of the introduction of ethyl alcohol and investigated objects. The obtained liver samples from each rat were divided into several parts. Some samples, after fixation in a $10 \%$ solution of formalin, were dehydrated in alcohols of increasing strength, poured into paraffin, transections were cut on a snuff-microtubule, stained with hematoxylin and eosin. Other samples, after fixation in formalin solution, were cut on a freezing microtome and sections were dyed with Sudan IV to detect neutral fat [10].

Illustrative material was prepared using light microscope Granum with digital camcorder Granum DCM 310. The photos were processed on a Pentium $2.4 \mathrm{GHz}$ computer using the Toup View program. 
Loss of drying of fresh plum fruits were determined as $76.89 \pm 2.26 \%$.

The results of determination of the content of polysaccharide fractions obtained from the fresh plum fruits are given in Table 1.

Table 1

Content of polysaccharide fractions from Prunus domestica fruits $(\mathrm{n}=3)$

\begin{tabular}{|c|c|}
\hline Polysaccharide fractions & Yield, $\%$ \\
\hline Fiber & $2.20 \pm 0.05$ \\
\hline WSPC & $1.13 \pm 0.05$ \\
\hline Pectin & $0.97 \pm 0.05$ \\
\hline
\end{tabular}

Obtained fiber was brown powder, WSPC - light brown and loose. The pectin was grayish brown and powdery texture.

The most content of neutral sugars were determined in the WSPS - 61.52 $\pm 1.47 \%$. Their content in other complexes was: in fibers $-59.23 \pm 1.15 \%$, pectin $22.85 \pm 0.55 \%$.

According to the analysis of the element composition, potassium has the most content in fruits -2000 $\mu \mathrm{g} / 100 \mathrm{~g}$. The content of other elements was $(\mu \mathrm{g} / 100 \mathrm{~g})$ : calcium -52 , magnesium -70 , sodium -50 , phosphorus -30 , silicon -15 , aluminum -1.5 , iron -1.0 , zinc -0.2 , strontium -0.8 , copper -0.25 , manganese -0.5 , molybdenum $\quad-\quad 0.05, \quad$ lead $<0.03$, nickel <0.03, Co $<0.03, \mathrm{Cd}<0.01$, As $<0.01, \mathrm{Hg}<0.01$. Content of elements was calculated on dried raw material. Our research determined that the content of heavy metals in the raw materials does not exceed the norms established by the State Pharmacopoeia of Ukraine.

According to our result it was confirmed that plum is an important source of potassium, which is known as a systemic electrolyte, regulator of water-salt metabolism, acid-base state of the organism; it promotes removal of edema; activates enzymes; also it is necessary for normal muscle activity, in particular, for the proper functioning of the heart, improves the functioning of the myocardium in the case of metabolic disorders [1]. The presence and content other elements also play role for health. For example, copper maintains the normal blood composition, is contained in enzymes and participates in the delivery of oxygen to the cells. Zinc strengthens immunity, is important for growth, and supports the hormonal background. Magnesium has an antispasmodic and antiplatelet effect [1].

As microscopy showed, the liver of intact rats had a typical structure inherent in this species of animals. Connective tissue layers between the lobes were not expressed. The boundaries of the particles were determined by triads - portal paths (passageways of the branches of the hepatic artery, reverse vein and bile duct). The triad zones themselves are narrow. The hepatocytes (liver proteins) in the lobes had a clear radial orientation. Hepatocytes in different parts of the liver lobules were of a characteristic shape and size, the cytoplasm was uniformly stained, optically dense, and did not contain inclusions visible in light microscopy. The nuclei of hepatocytes were normochromic, centrally located, containing 1-2 nucleoli. The number of dual-core hepatocytes was sufficient. The intracellular hemocapillaries were moderately enlarged, containing the usual number of lymphoid cells. Kupffer cells without features (Fig. 1). Sudan coloring did not reveal the accumulation of fat in the cytoplasm of cells (Fig. 2).

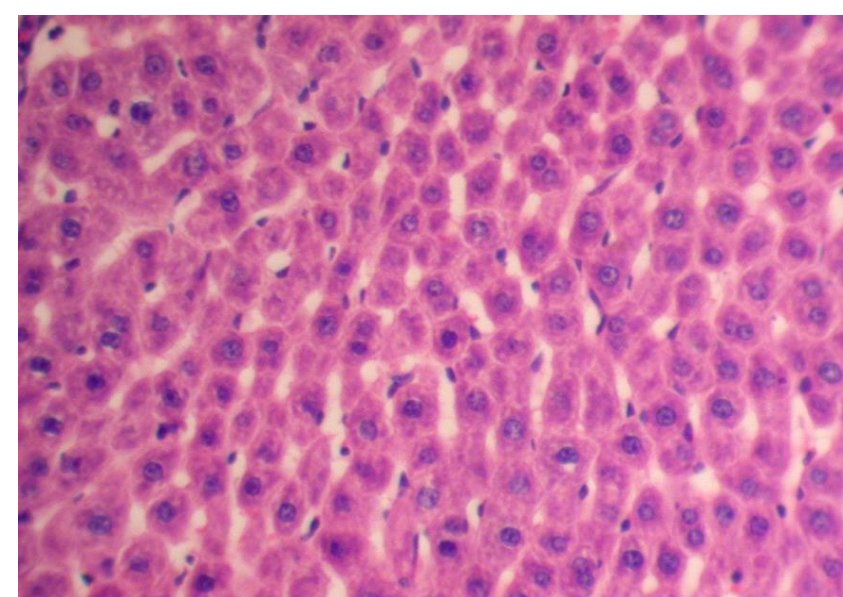

Fig. 1. Liver of an intact rat. Normal state of the liver parenchyma. Hematoxylin-eosin. $\times 250$

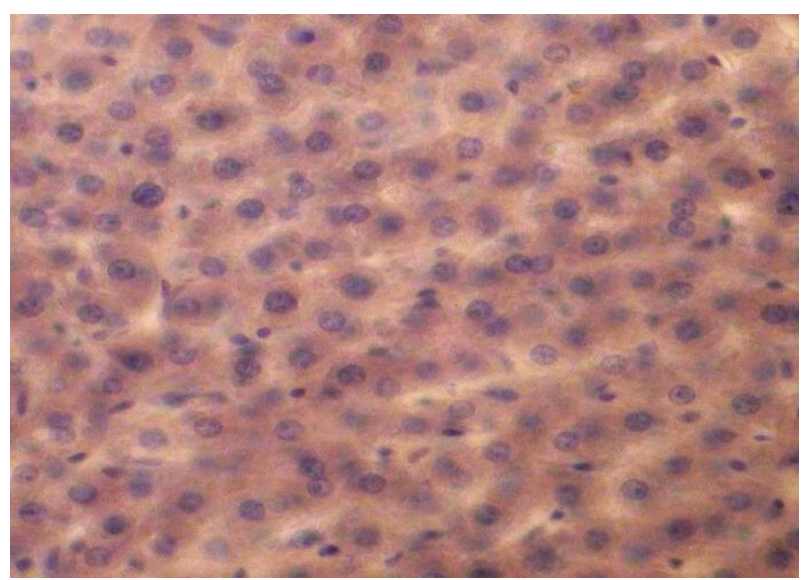

Fig. 2. Liver of intact rat. Absence of fat in the cytoplasm of hepatocytes frozen transection, Sudan IV. $\times 250$

Sinusoidal hemocapillars are unevenly enlarged, cities are full-blooded. Hepatocytes and their nuclei vary somewhat in size. Cell nuclei were slightly hyperchromic, nucleoli differed not clearly. Kupffer cells were activated in cites. Vacuolation of cytoplasm of hepatocytes was diffusely or large focal part of the lobules. Inflammatory reactions, necrosis of hepatocytes are absent (Fig. 3). Sudan coloring revealed the fatty nature of vacuoles. Fat drops had a small drop nature, did not destroy the integrity of the cells, did not cause the dislocation of the nucleus (Fig. 4).

The microscopic picture above corresponds to parenchymal fatty degeneration of the hepatic parenchyma. Taking into account the previous "alcoholization" as an experimental condition, this picture may be a manifestation of the very initial stage of alcoholic hepatopathy [11].

Simultaneous administration ethanol and fibers of plum fruit positively influenced on the condition of the liver parenchyma. Hepatocysts contained juicy nuclei, nucleoli were clear, less pronounced anisonuclease. The vacuolation of cells was clearly reduced, with a small 
focal nature. The parenchyma of the particles was predominantly normal in shape (Fig. 5).

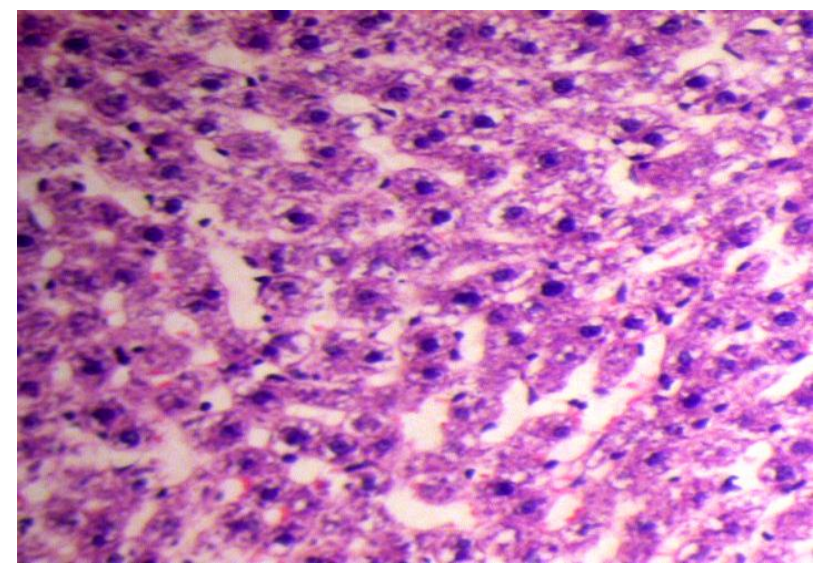

Fig. 3. Rat liver after ethanol administration. Diffuse small droplet of vacuoles in hepatocytes, inflammatory reaction and cell necrosis is absent. Hematoxylin-eosin. $\times 250$

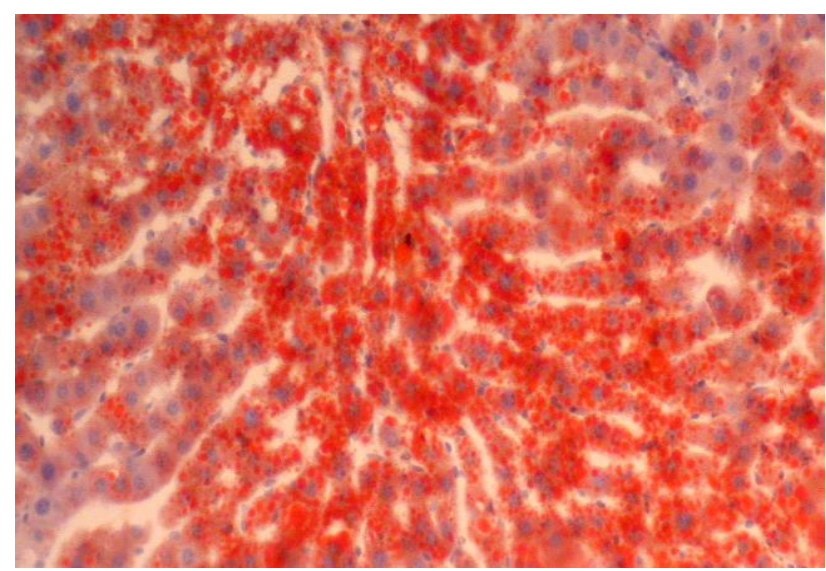

Fig. 4. Rat liver after ethanol administration. Neutral fat accumulation in cytoplasm of hepatocytes, frozen tissue slices, Sudan IV. $\times 200$

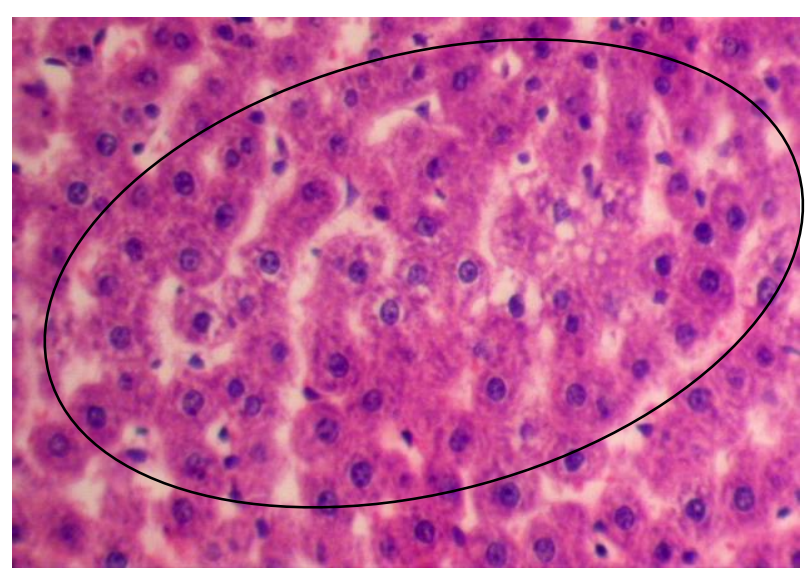

Fig. 5. Rat liver, which on the background of ethyl alcohol was treated by plum fruit fibers. Fractal-focal character of vacuolization of hepatocytes against the background of unchanged parenchyma. Hematoxylin-eosin $\times 300$
Sudan coloring showed that fatty drops in the cytoplasm of hepatocytes were very small, often had a dusty character (Fig. 6).

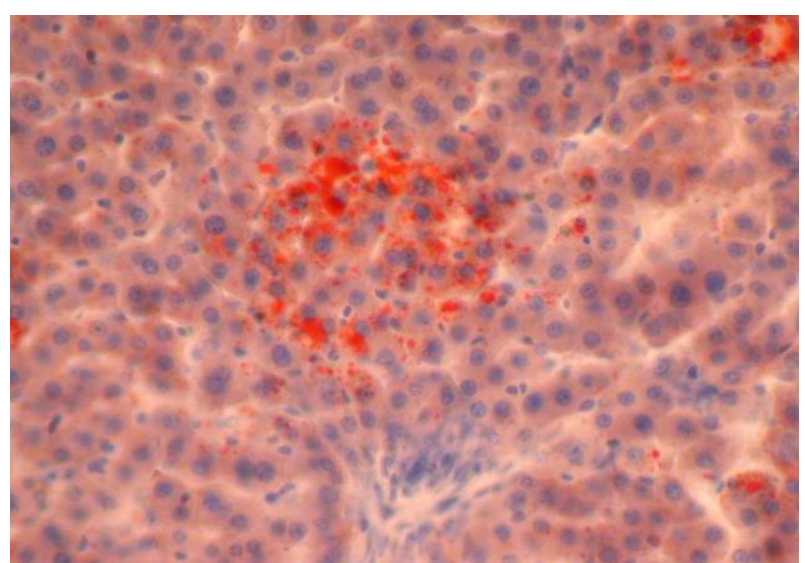

Fig. 6. Rat liver, which on the background of ethyl alcohol was injected with a fiber of plum fruit. Fatty drops in the cytoplasm of cells were small or pinnate. Frozen tissue slices, Sudan IV. $\times 250$

Introduction to the background of alcohol of the WSPC of plum fruit visually had little effect on the expressiveness of the vacuolization of hepatocytes compared to the control pathology and the state of the hepatic parenchyma in general. The processes of microcirculation in the lobes are also comparable (Fig. 7). Fat drops did not break either the beam pattern or cell integrity (Fig. 8).

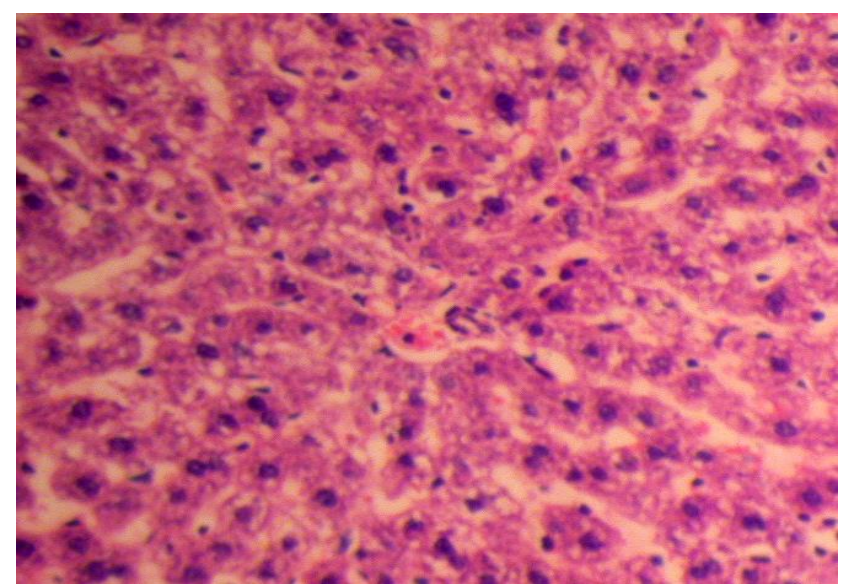

Fig. 7. Rat liver, which on the background of ethyl alcohol was injected WSPC of plum fruit. Diffuse vacuolation of hepatocytes. Hematoxylin-eosin. $\times 200$

Comparison drug silibor also did not prevent the occurrence of fatty dystrophy of hepatocytes in rats with alcoholic loading. The expressiveness of changes was practically at the level of the last (Fig. 9, 10).

Thus, a light-optical study showed that after 7-10 days of administration of $40 \mathrm{ml}$ of ethyl alcohol in rats at a dose of $7 \mathrm{ml} / \mathrm{kg}$ in the rats liver, morphological signs of parenchymal fatty degeneration appeared, which may be the very initial stage of alcoholic hepatopathy development. 


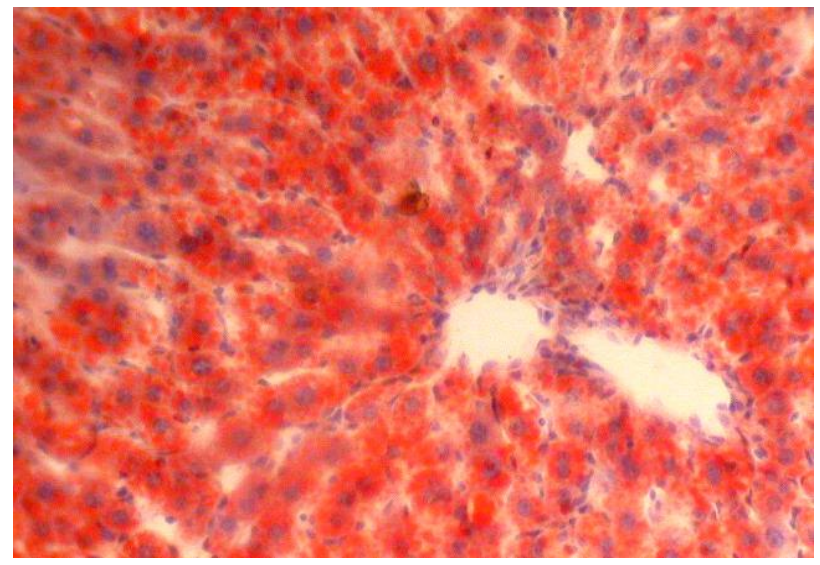

Fig. 8. Rat liver, which on the background of ethyl alcohol was injected WSPC of plum fruit. Small drops of fat in hepatocytes were diffuse in the lobe. Frozen tissue slices, Sudan IV. x200

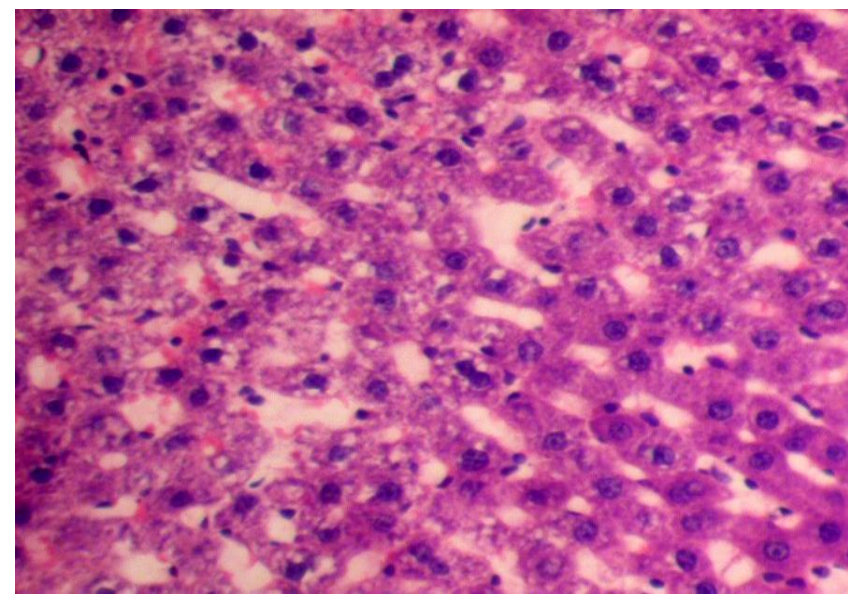

Fig. 9. Rat liver, which on the background of ethyl alcohol injected silibor. The protein pattern is unchanged, small vacuoles in the cytoplasm of virtually all hepatocytes Hematoxylin-eosin. $\times 250$

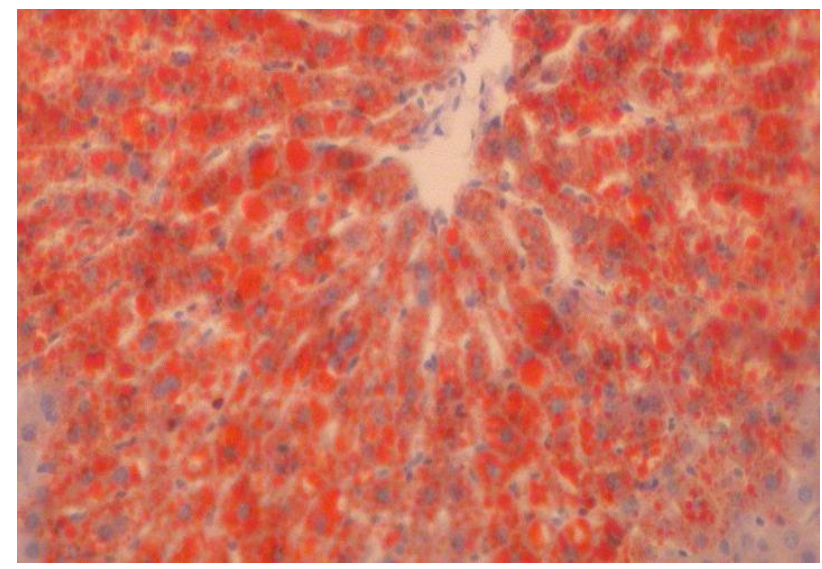

Fig. 10. Rat liver, which on the background of alcohol was injected silibor. The diffuse nature of the distribution of fat droplets. Frozen tissue slices, Sudan IV . $\times 200$

Simultaneous administration of alcohol and fiber of fruit plums in a dose of $200 \mathrm{mg} / \mathrm{kg}$ prevents the development of fatty dystrophy of the liver parenchyma, in contrast to the similar scheme of the introduction of a WSPC of plum fruit in the same dose or drug comparison of silibor at a dose of $30 \mathrm{mg} / \mathrm{kg}$.

\section{Conclusions}

1. Investigation of element composition of plum fruits was carried out.

2. Polysaccharide complexes of plum fruits were obtained and content of neutral sugars were determined there.

3. It was confirmed that simultaneous administration of alcohol with the fibers of plum fruits in a dose of 200 $\mathrm{mg} / \mathrm{kg}$ prevents the development of fatty dystrophy of the liver parenchyma, in contrast to the similar scheme of the administration of the WSPC of plum fruit in the same dose or drug comparison silibor at a dose of $30 \mathrm{mg} / \mathrm{kg}$.

Considering results of phytochemical and pharmacological research, we can assume that the plum fruit fiber is promising for further study in order to create a new effective and safe drugs for use in medical practice.

\section{References}

1. Farmatsevtychna entsyklopediya / ed. by Chernykh V. P. Kyiv: MORION, 2010. 1952 p.

2. Stickney J. C., Van Liere E. J., Northup D. W. Correlation Between Propulsive Motility and Length of the Small Intestine in Albino Rats and Dogs // American Journal of Physiology-Legacy Content. 1951. Vol. 167, Issue 2. P. 399-402. doi: http://doi.org/ 10.1152/ajplegacy.1951.167.2.399

3. Determination of phenolic compounds, antioxidant capacity and organic acids contents of Prunus domestica L., Prunus cerasifera Ehrh. and Prunus spinosa L. fruits by HPLC / Celik F. et. al. // Acta Chromatographica. 2017. Vol. 29, Issue 4. P. 507-510. doi: http://doi.org/10.1556/1326.2017.00327

4. Senyuk I. V., Bashar A.-S. J., Lenchyk L. V. Investigation of different substances catharic properties made from Prunus domestica // Ukrainian biopharmaceutical journal. 2017. Issue 5 (52). P. 21-25. doi: http://doi.org/10.24959/ubphj.17.134

5. Mohammed Shahm Basim, Lenchik L. V., Caidov N. B. Plody slivy domashney - perspektivnoe syr'e dlya sozdaniya lekarstvennyh sredstv // Nauka i innovaciya. Seriya estestvennyh nauk. 2017. Issue 4. P. 42-48. 2008. $620 \mathrm{p}$.

6. The State Pharmacopoeia of Ukraine / State Enterprise "Ukrainian scientific Pharmacopoeial center". Kharkiv: RIREG,

7. Doslidzhennia aminokyslotnoho ta monotsukrovoho skladu spyrtovoho ekstraktu z lystia evkaliptu prutovydnoho / Koshovyi O. M. et. al. // Farmakom. 2012. Issue 1-2. P. 46-49.

8. Elementniy sostav bagul'nika bolotnogo / Belousov M. V. et. al. // Himiya rastitel'nogo syr'ya. 2002. Issue 4. P. 35-38.

9. Kabata-Pendias A. Trace elements in soils and plants. 4th ed. New York: CRC press, 2010. 548 p. doi: http://doi.org/10.1201/b10158

10. Merkulov G. A. Kurs patologogistologicheskoy tekhniki. Leningrad: Medicina, 1969. 424 p.

11. Serov V. V., Lapish K. Morfologicheskaya diagnostika zabolevaniy pecheni. Moscow: Medicina, 1989. 336 p. 
Taras Upyr, Assistant, Department of Pharmacognosy, National University of Pharmacy, Pushkinska str., 53, Kharkiv, Ukraine, 61002

E-mail: froyd1856@gmail.com

Shahm Basim Mohammed, Postgraduate Student, Department of Chemistry of Natural Compounds, National University of Pharmacy, Pushkinska str., 53, Kharkiv, Ukraine, 61002

Bashar Al-Jabbar Ali Sahlani, Postgraduate Student, Department of Biological Chemistry, National University of Pharmacy, Pushkinska str., 53, Kharkiv, Ukraine, 61002

Larysa Lenchyk, Doctor of Pharmaceutical Sciences, Associate Professor, Department of Chemistry of Natural Compounds, National University of Pharmacy, Pushkinska str., 53, Kharkiv, Ukraine, 61002

E-mail: larysa.lenchyk@gmail.com

Igor Senyuk, PhD, Associate Professor, Department of Biological Chemistry, National University of Pharmacy, Pushkinska str., 53, Kharkiv, Ukraine, 61002

E-mail: citochrom@gmail.com

Viktoria Kyslychenko, Doctor of Pharmaceutical Sciences, Professor, Department of Chemistry of Natural Compounds, National University of Pharmacy, Pushkinska str., 53, Kharkiv, Ukraine, 61002

E-mail: cncvc55@gmail.com

UDC 615.012.014

DOI: 10.15587/2519-4852.2018.135874

\section{DYNAMICS OF EXCEPTION OF ORGANIC ACIDS FROM MIXTURE OF MEDICAL VEGETABLE RAW MATERIAL}

\section{(C) I. Dyachok, O. Pinyazhko, O. Ivankiv}

Мета. Отримання математичних рівнянь для обчислення розміру частин різних морфологічних органів рослинної сировини для одночасного досягнення рівноваги при сумісному екстрагуванні.

Методи. 3 огляду на тенденцію до зростання рівня психопатологічних розладів, дочільним є розроблення та впровадження у медичну практику седативних засобів на основі комплексних фітополіекстрактів, одержаних із лікарської рослинної сировини. Сучасні дані про хімічний склад, фармакологічну дію, застосування в світовій медччній практиці дозволяють позитивно оцінити тенденції застосування лікарської рослинної сировини для одержання фітополіекстрактів седативної дії. Зростаючі вимоги до якості лікарських засобів рослинного походження є передумовою розроблення науково-обтрунтованих методологій отримфння фітополіекстрактів.

Результати. Представлені результати досліджень розробки методики аналітичного розрахунку розміру частинок рослинної сировини різних морфологічних органів з метою одночасного досягнення заданного ступеня вилучення органічних кислот і інших біологічно активних речовин при сумісному екстрагуванні.

Висновки. Одержані аналітичні залежності описують динаміку вилучення органічних кислот із лікарської рослинної сировини. Вирімення системи одержаних математичних рівнянь дозволяє розрахувати розмір до якого необхідно подрібнювати рослинну сировину різних морфологічних органів 3 метою одночасного досягнення заданного ступеня вилучення при сумісному екстрагуванні суміші лікарської рослинної сировини. Отримані результати свідчать про перспективність досліджень сумісного екстрагування лікарської рослинної сировини з метою одержання природніх біологічно активних речовин для виготовлення полікомпонентних фітопрепаратів

Ключові слова: лікарська рослинна сировина, органічні кислоти, динаміка вилучення біологічно активних сполук, фітополіекстракт

\section{Introduction}

Globally, there is a clear trend to higher level of psychopathological disorders, in particular a variety of psychogenic neurotic disorders. In Ukraine, the situation is complicated by various social-psychological problems, global informational oversaturation, chronic fatigue, environmental problems, the decline in the quality of life. All this leads to the onset of stress which manifests itself as fatigue, decreased performances, irritability, anxiety, worsened mood, disrupted sleep, etc. For the treatment of neurotic conditions, the most effective means are the phytogenic sedatives of plant origin due to the similarity of many biochemical processes in the cells of plant and animal origin. This property becomes particularly important when it concerns treatment and prophylactic means. The particular interest of doctors and patients in these sedatives can be explained by the minimum of contraindications and side effects [1]. 